\title{
A multiple T cell epitope comprising DNA vaccine boosts the protective efficacy of Bacillus Calmette-Guérin (BCG) against Mycobacterium tuberculosis
}

Sudeep Kumar Maurya ${ }^{1}$, Mohammad Aqdas ${ }^{1}$, Deepjyoti Kumar Das ${ }^{1}$, Sanpreet Singh', Sajid Nadeem', Gurpreet Kaur ${ }^{1}$ and Javed Naim Agrewala ${ }^{1,2^{*}}$ (D)

\begin{abstract}
Background: Approximately $80 \%$ - 90\% of individuals infected with latent Mycobacterium tuberculosis (Mtb) remain protected throughout their life-span. The release of unique, latent-phase antigens are known to have a protective role in the immune response against Mtb. Although the BCG vaccine has been administered for nine decades to provide immunity against $M t b$, the number of TB cases continues to rise, thereby raising doubts on BCG vaccine efficacy. The shortcomings of BCG have been associated with inadequate processing and presentation of its antigens, an inability to optimally activate $T$ cells against $M t b$, and generation of regulatory $T$ cells. Furthermore, BCG vaccination lacks the ability to eliminate latent $M$ tb infection. With these facts in mind, we selected six immunodominant CD4 and CD8 T cell epitopes of Mtb expressed during latent, acute, and chronic stages of infection and engineered a multi-epitope-based DNA vaccine (C6).
\end{abstract}

Result: BALB/c mice vaccinated with the $C 6$ construct along with a BCG vaccine exhibited an expansion of both CD4 and CD8 T cell memory populations and augmented IFN- $\gamma$ and TNF-a cytokine release.

Furthermore, enhancement of dendritic cell and macrophage activation was noted. Consequently, illustrating the elicitation of immunity that helps in the protection against Mtb infection; which was evident by a significant reduction in the Mtb burden in the lungs and spleen of C6 + BCG administered animals.

Conclusion: Overall, the results suggest that a C $6+B C G$ vaccination approach may serve as an effective vaccination strategy in future attempts to control TB.

Keywords: T cells, Epitopes, DNA vaccine, BCG, Tuberculosis

\footnotetext{
*Correspondence: jagrewala@gmail.com

${ }^{1}$ CSIR-Institute of Microbial Technology, Chandigarh 160036, India

${ }^{2}$ Present Address: Indian Institute of Technology, Rupnagar 140001, India
}

C C The Author(s). 2020 Open Access This article is licensed under a Creative Commons Attribution 4.0 International License, which permits use, sharing, adaptation, distribution and reproduction in any medium or format, as long as you give appropriate credit to the original author(s) and the source, provide a link to the Creative Commons licence, and indicate if changes were made. The images or other third party material in this article are included in the article's Creative Commons licence, unless indicated otherwise in a credit line to the material. If material is not included in the article's Creative Commons licence and your intended use is not permitted by statutory regulation or exceeds the permitted use, you will need to obtain permission directly from the copyright holder. To view a copy of this licence, visit http://creativecommons.org/licenses/by/4.0/. The Creative Commons Public Domain Dedication waiver (http://creativecommons.org/publicdomain/zero/1.0/) applies to the data made available in this article, unless otherwise stated in a credit line to the data. 


\section{Background}

Mycobacterium tuberculosis (Mtb) kills 1.5 million people annually [1]. Furthermore, the increasing frequency of $M t b$ cases exhibiting drug-resistance warrants the need to develop better vaccines or strategies for the prevention and treatment of TB [2]. The only available vaccine for TB is an attenuated form of Mycobacterium bovis named as Bacillus Calmette-Guérin (BCG) [3]. The efficacy of BCG is poor in populations with a high TB-burden [4]. BCG has proven its efficacy against childhood, but not adulthood manifestation of the disease, depicting an inability to generate enduring memory $\mathrm{T}$ cells against $M t b$. BCG has lost the RD1 region from its genome. Although RD1 provides virulence in $M t b$, it also evokes strong protective immunity against the bacterium signifying that BCG requires supplementation with certain $M t b$ proteins to improve its protective efficacy $[5,6]$. In this regard, several prime-boost studies were conducted with BCG, such as protein and peptidebased subunit vaccines, live attenuated vaccines, and viral vectors with promising results [7].

Recently, we developed a lipidated promiscuous peptide vaccine comprising of the immunodominant CD4 and CD8 T cell epitopes of Acr1 and TB10.4 proteins of $M t b$ conjugated to TLR-2 ligand Pam2Cys $[8,9]$. These constructs elicited enduring memory $\mathrm{T}$ cells response and showed better protection than BCG in mouse and Guinea pig TB models. Several advantages are associated with peptide vaccines, such as the selection of immunodominant moieties and the elimination of suppressive and auto-reactive portions of the antigen. However, there are certain issues associated with peptide vaccines due to its cost-effectiveness and synthesis for mass immunization. Hence, expressing the immunodominant epitopes inside the host could be an effective mode to eliminate the issues. An effective mode of expressing the epitopes would be the DNA vaccine strategy. A major advantage of DNA vaccines is that they are simpler to produce and store compared to conventional vaccines, making them less expensive. DNA vaccines can elicit the generation of both CD4 Th1 cells, CD8 T cells, and long-lasting immunity; the immune response that plays a cardinal role in protection against $M t b$ [10].
This encouraged us to design a DNA vaccine comprising of six CD4 T cells and CD8 T cells epitopes of latency, active and chronic stages of $M t b$. To check the efficacy of the vaccine, it is important to use an animal model of TB and mice are very useful as their adaptive immune response is similar to humans. Hence, we immunized mice with DNA vaccine and observed induction of protective immune response that significantly reduced the frequency of bacterium in the animals exposed to $M t b$. Furthermore, the vaccine considerably improved the efficacy of BCG to protect against $M t b$. This vaccine may have future implications in protecting individuals from $\mathrm{TB}$.

\section{Results}

\section{Selection of T cell epitopes and construction of their sequence}

To boost BCG efficacy, immunodominant $T$ cell epitopes from different spectrums of TB as from latent, active, and chronic were selected from published literature [11-14]. The epitopes were promiscuous and showed the potential to elicit CD4 $\mathrm{T}$ cell and CD8 $\mathrm{T}$ cell response against $M t b$. All the epitopes exhibited the ability to bind diverse HLA molecules. The six most immunodominant $\mathrm{T}$ cell epitopes were selected from Acr1, TB10.4, CFP10, and Rv0476 Mtb antigens (Table 1). The sequences were arranged in duplicates to increase the dose of the antigen (Fig. 1a). To segregate peptides during the process of antigen presentation, the chosen peptides were designed to have linkers that could be cleaved specifically by proteases present in antigen-presenting cells (APCs). To achieve this, the peptide sequences were checked for their sensitivity to proteases through in silico software PROSPER [15]. The Rv0476 peptide was found to be most sensitive to enzymatic cleavage and therefore was used as a linker between the epitopes (Supplementary Fig. 1a). The amino acid sequence AVYAFVH of epitope Rv0476 $(1-19)$ was used as a linker between the epitopes. The initial two amino acid sequence is variable due to the presence of similarly charged amino acid sequence at the end of epitopes. To introduce a secretory signal in the protein, we added an

Table 1 Selected T cell epitopes

\begin{tabular}{lllll}
\hline Sr. No. & Protein & Sequence & TB spectrum & Reference \\
\hline 1 & TB10.4 $_{(1-13)}$ & MSQIMYNYPAMLG & Active & {$[12]$} \\
2 & TB10.4 $_{(78-94)}$ & ANTMAMMARDTAEAAKW & Active & {$[12]$} \\
3 & $\operatorname{Rv0476}_{(1-19)}$ & MLVLLVAVLVTAVYAFVHA & Active and latent & {$[13]$} \\
4 & $\mathrm{CFP10}_{(71-90)}$ & EISTNIRQAGVQYSRADEEQ & Active & {$[14]$} \\
5 & $\operatorname{Acr}_{(91-110)}$ & SEFAYGSFVRTVSLPVGADE & Latent & {$[11]$} \\
6 & $\operatorname{Acr}_{(21-40)}$ & LFAAFPSFAGLRPTFDTRLM & Latent & {$[11]$} \\
\hline
\end{tabular}




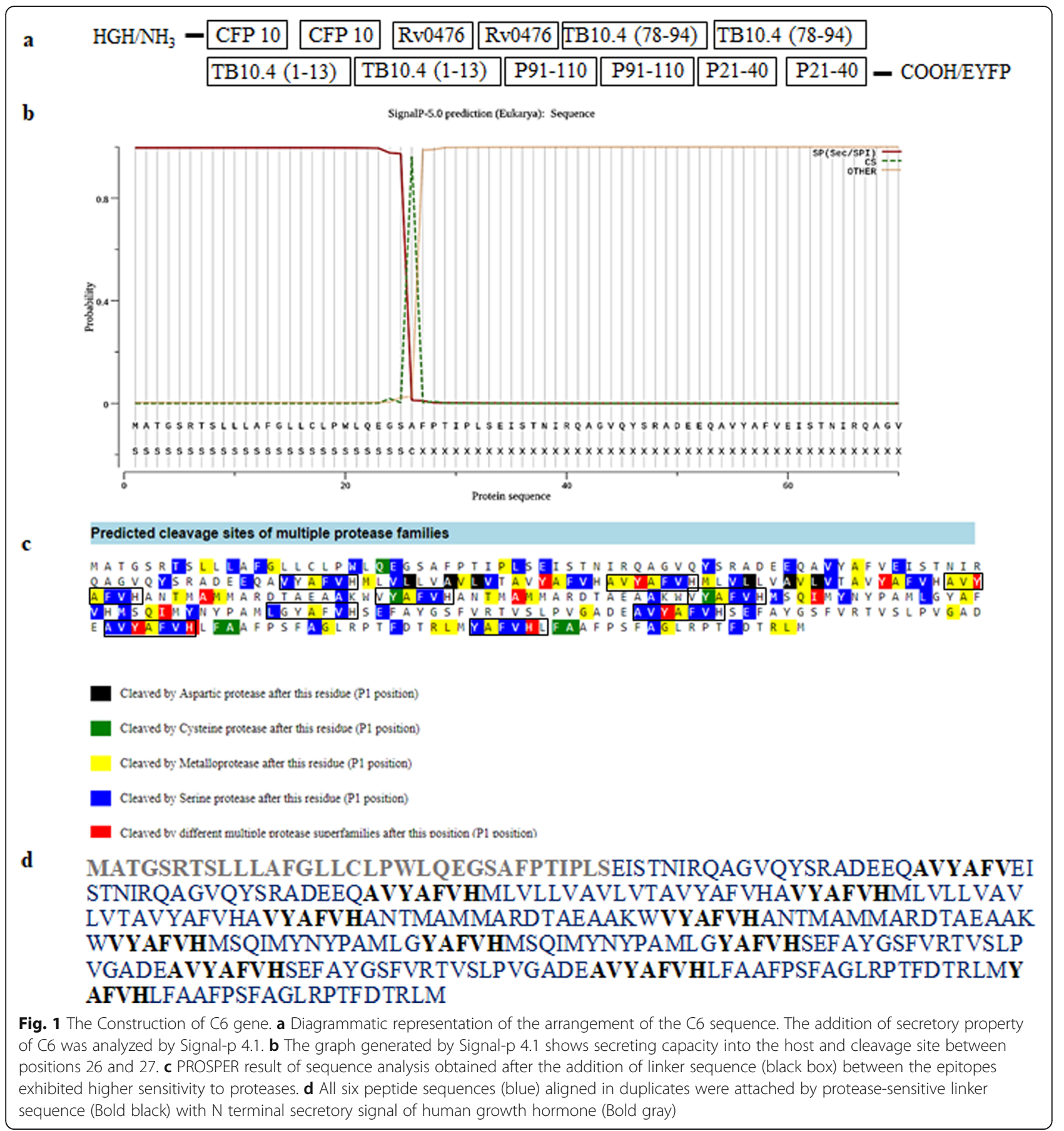

$\mathrm{N}$ Terminal sequence of Human growth hormone (HGH), as a secretory signal [16]. The whole sequence (named and hereon referred to as C6) was further tested for its secretory capability in mammalian host cells. To analyze its release, Signal 4.1 server was used [17]. The Signal 4.1 server showed the $\mathrm{N}$ terminal secretory signal with secretion capability of protein and its cleavage site (Fig. 1b). The complete amino acid sequence was analyzed again in PROSPER to check the protease sensitivity of the linkers. The result indicated a higher sensitivity of linkers compared to the rest of the sequence (Fig. 1c). The final amino acid sequence of $\mathrm{C} 6$ was used for gene synthesis (Fig. 1d, Supplementary Fig. 1b).

\section{Expression analysis of the selected T cell epitope-based gene construct}

To use the C6 gene as a vaccine, a suitable vector must be used for its expression. Consequently, the C6 gene 
was cloned in pcDNA3.1(-) for immunization. Yellow fluorescent-tagged variants were generated for the expression analysis (Fig. 2a, Supplementary Fig. 2a-c). We transfected $\mathrm{C} 6$ gene in $\mathrm{CHO}$ cells and subsequently checked for its expression. The YFP-tagged C6 cells were observed under a fluorescence microscope (Fig. 2b). The transfected cells were further analyzed by flow cytometry. The decreased fluorescence intensity indicated the expression of the additional protein (C6) with YFP (Supplementary Fig. 3a, b).

Further, total cell lysate of transfected $\mathrm{CHO}$ cells and culture SNs precipitate was used for Western blotting.
The cells expressing YFP with C6 were observed as a band of $57 \mathrm{kDa}$ molecular weight (mwt) in the blot. The YFP alone appeared at mwt of $25 \mathrm{kDa}$. The expression of YFP attached with $\mathrm{C6}$ indicates the secretion of protein in SN (Fig. 2c). Both fluorescent microscopy and Western blotting results confirmed in vitro expression of C6.

It is important for a DNA vaccine to get expressed in host cells and subsequently produce antigens and prime the cells of the immune system. To accomplish this, mice were immunized intramuscular (i.m.) with plasmid C6YFP and control vector. The animals were rested for $3 \mathrm{~d}$ and YFP expression was checked in the lymph nodes

a

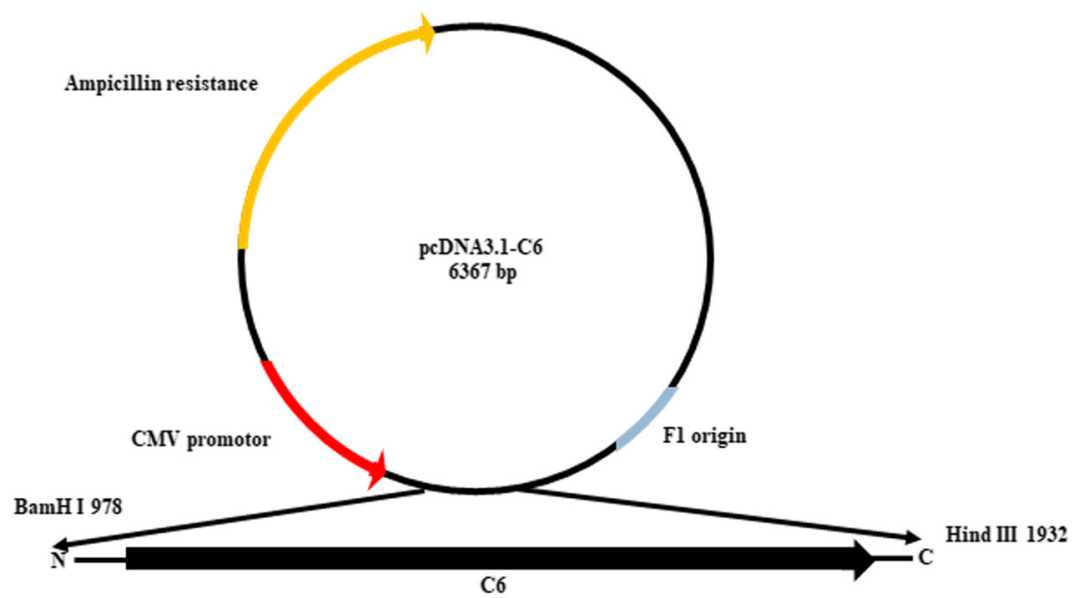

b
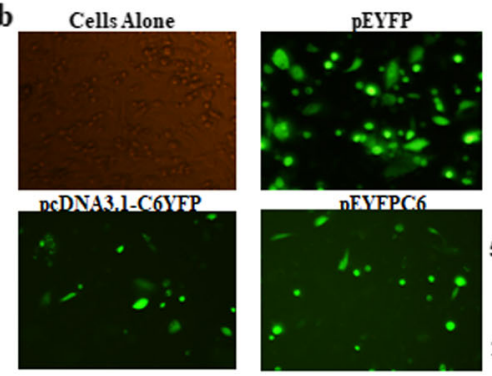

c

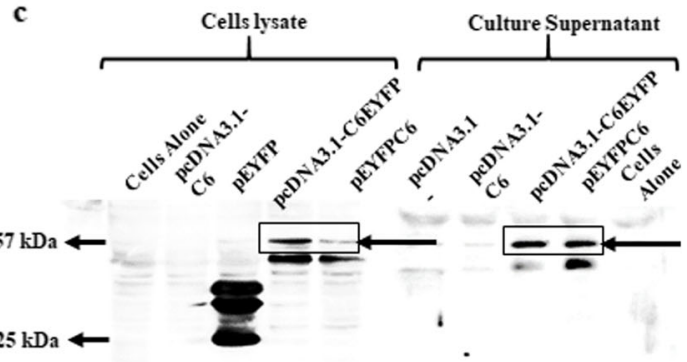

d

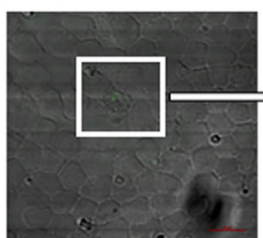

Lymph nodes

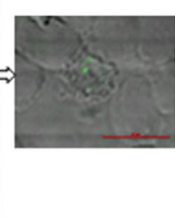

(1)

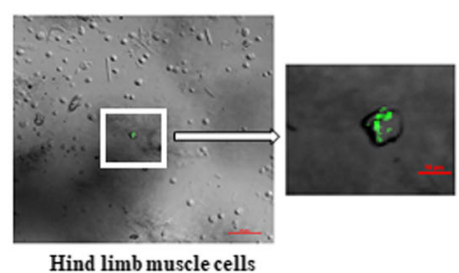

Fig. 2 The constructed C6 gene expresses chimeric protein. a Vector map of DNA vaccine where C6 is cloned in between the BamHI and HindIII sites. b CHO cells were transfected with pcDNA3.1-C6, control pEYFP, and pEYFPC6 plasmids. After $24 \mathrm{~h}$, the cells were analyzed under a fluorescent microscope. The transfected $\mathrm{CHO}$ cells with plasmids were harvested after $24 \mathrm{~h}$ of transfection. c The C6 expressing YFP was assessed in both cell lysate and SNs of transfected CHO cells through Western blotting. The protein bands in the inset signify a shift of the YFP band from 25 to $57 \mathrm{kDa}$. d C6 was inoculated into the hind limb of mice. Three days later, the cells from inguinal LNs and hind limb muscles were harvested and monitored by confocal microscopy for YFP expression. Lymph node cells and the hind limb cells showed YFP expression. The data are representative of 3 independent experiments 
and hind limb muscles via confocal microscopy. We observed YFP expression in both cell types, thus confirming the expression of $\mathrm{C} 6$ in vivo (Fig. 2d).

Immunization with BCG + C6 augments the T cell memory After confirmation of YFP expression, we wanted to check the viability of $\mathrm{C} 6$ as a vaccine candidate and its ability to enhance the efficacy of BCG. Therefore, we immunized mice with BCG, C6, and controls (Negative, vector control), subsequently infecting them with Mtb aerosol. After 30d we assessed each group's immune response (Fig. 3a). Generation of persistent memory $\mathrm{T}$ cells against a pathogen is essential for any successful vaccine. PPD is a rich source of $M t b$ antigens and is used to check the immune response against $M t b$. We have used 6 different $\mathrm{T}$ cells epitopes of $M t b$ in DNA vaccine to induce an immune response against these epitopes. So, it is important to check the immune response against these epitopes as well. Therefore, we examined $\mathrm{T}$ cell memory response following C6 immunization. Spleen and lymph node-derived lymphocytes were stimulated in vitro either with PPD or mixture of peptides to monitor the expression of memory markers CD44 $4^{\text {hi }}$ and $\mathrm{CD}_{22} \mathrm{~L}^{\text {hi }}$ on CD4 and CD8 T cells (Fig. 3b-g). We observed an increased percentage of $\mathrm{CD} 62 \mathrm{~L}^{\text {hi }} \mathrm{CD} 44^{\text {hi }}$ expressing memory CD4 T cells (PPD: $p<0.05$ ) and CD8 T cells (PPD: $p<0.05)$ in C6 immunized mice, as compared to BCG on in vitro stimulation with PPD (Fig. 3b-d). However, in vitro stimulation with C6 peptides showed a non-significant increase in memory CD4 and CD8 $\mathrm{T}$ cell frequency (Fig. 3e-g). Furthermore, we observed that C6 bolstered the generation of memory CD4 T cells (PPD: $p<0.05$, Peptides: $(p<0.005)$ and CD8 T cells (PPD: $p<0.05$, Peptides: $(p<0.05)$ in the group that was vaccinated with BCG (BCG + C6) compared to BCG alone. Furthermore, we observed an expansion in the pool of memory $\mathrm{T}$ cells in the lungs of the same animals (Supplementary Fig. 4a-d). These results indicate the potential of C6 to not only expand memory CD4 T cells and CD8 $\mathrm{T}$ cells but to also boost memory $\mathrm{T}$ cell generation associated with BCG.

Combinatorial administration of BCG + C6 improves the secretion of IFN- $\gamma$, TNF- $a$, and inhibits IL-10 release

Mounting of a Th1 immune response is crucial for combatting $M t b$ infection [18]. IFN- $\gamma$ and TNF- $\alpha$ released by Th1 cells both serve an important function in $M t b$ infection by activating phagocytic cells [19]. Therefore, we checked if BCG + C6 immunization can enhance IFN- $\gamma$ and TNF- $\alpha$ secretion by in vitro stimulation with PPD

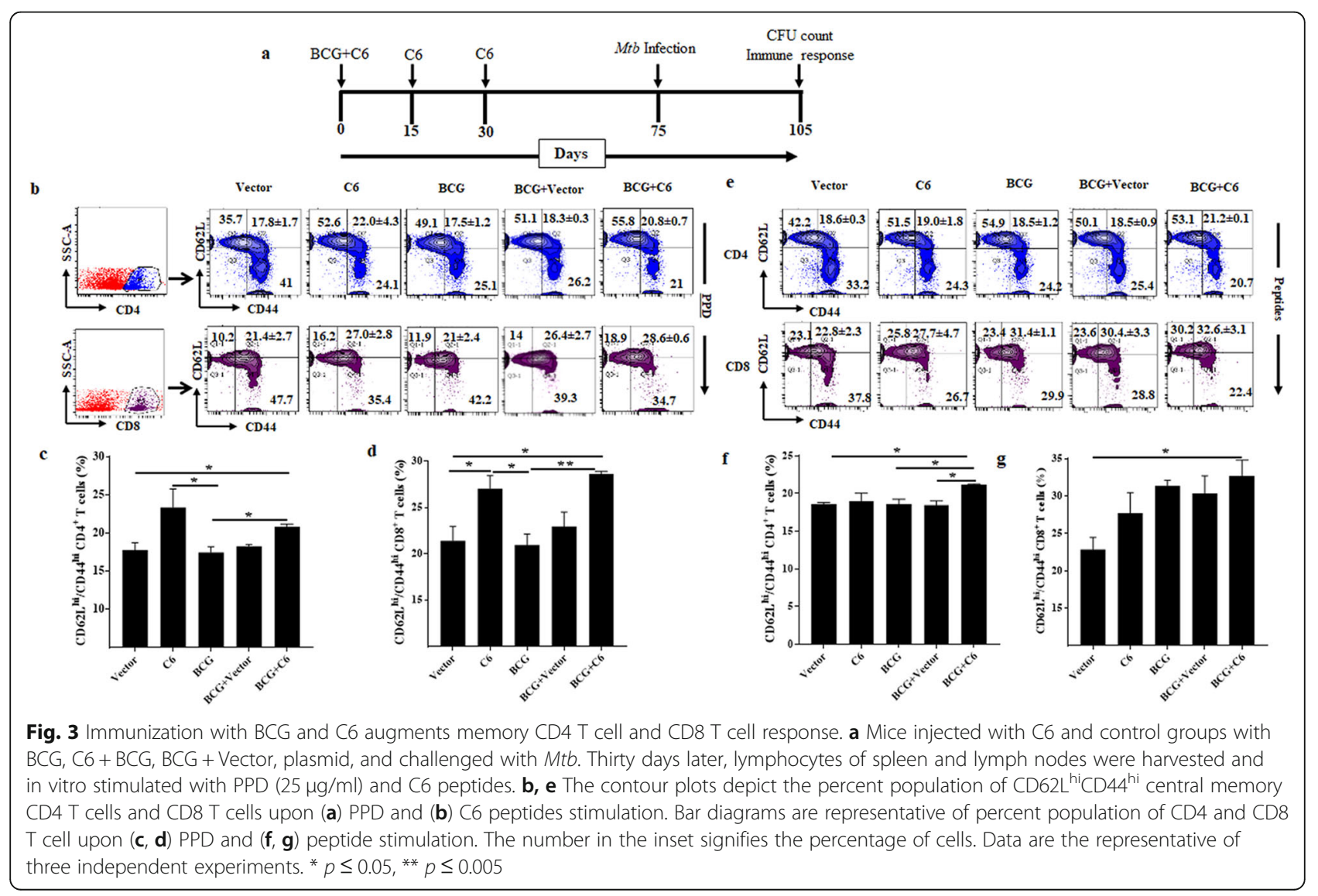


and peptides. It was found that immunization with BCG + C6 significantly increased the production of IFN $-\gamma$ (PPD: $p<0.05$, peptides: $p<0.05$ ) and TNF- $\alpha$ (PPD: $p<0.05$, peptides: $p<0.005$ ) as compared to a vector control. We found that BCG vaccination alone showed no significant increase in such cytokine production (Fig. 4a, b). C6 alone showed insignificant increases in IFN- $\gamma$ and TNF- $\alpha$ release. Surprisingly, we observed an increased level of IL-10 $(p<0.05)$ in BCG immunized group compared to the vector control. In contrast, IL-10 production in BCG + C6 immunized animals was significantly lower $(p<0.05)$ upon immunization in comparison to BCG control, indicating a capability to promote Th1 response (Fig. 4c). These results support the generation of Th1 immunity against $M t b$ upon BCG + C6 immunization.

\section{Immunization with $\mathrm{C} 6$ promotes the activation of antigen-presenting cells}

The immune system responsible for the clearance of pathogens is primarily antigen-presenting cells (APCs), such as macrophages and dendritic cells (DCs) [20, 21].
$M t b$ is known to modulate APCs to prevent the activation and expression of MHC and co-stimulatory molecules [20-22]. Therefore, we wanted to examine the immune status of APCs in the lungs upon C6 administration from $M t b$ infected mice. It was found that upon stimulation with LPS, the percentage of $\mathrm{MHC}-\mathrm{II}^{\mathrm{hi}}$, CD86 ${ }^{\text {hi }}$, and CD40 ${ }^{\text {hi }}$ expressing DCs isolated from the lungs was greater in $\mathrm{C} 6$ and $\mathrm{BCG}+\mathrm{C} 6$ inoculations as compared to their respective controls (vector, BCG) (Fig. 5a, b). Similarly, the percentage of MHC-II ${ }^{\text {hi }}$, $\mathrm{CD} 86^{\mathrm{hi}}$, and $\mathrm{CD} 40^{\mathrm{hi}}$ expressing macrophages were also higher in $\mathrm{C} 6$ and BCG + C6 groups than controls (Fig. $5 \mathrm{c}, \mathrm{d})$. However, there was a considerable decrease in the percent population of CD80 ${ }^{\mathrm{hi}}$ expressing DCs and macrophages. Similar results were observed with DCs and macrophages isolated from the spleen and lymph nodes (Supplementary Fig. 5a-e).

Among several cytokines produced by activated DCs, IL-6 and IL-12 are quite crucial since they play a fundamental role in the differentiation of naïve $\mathrm{CD} 4 \mathrm{~T}$ cells into Th1 cells $[20,21]$ Interestingly, we observed that

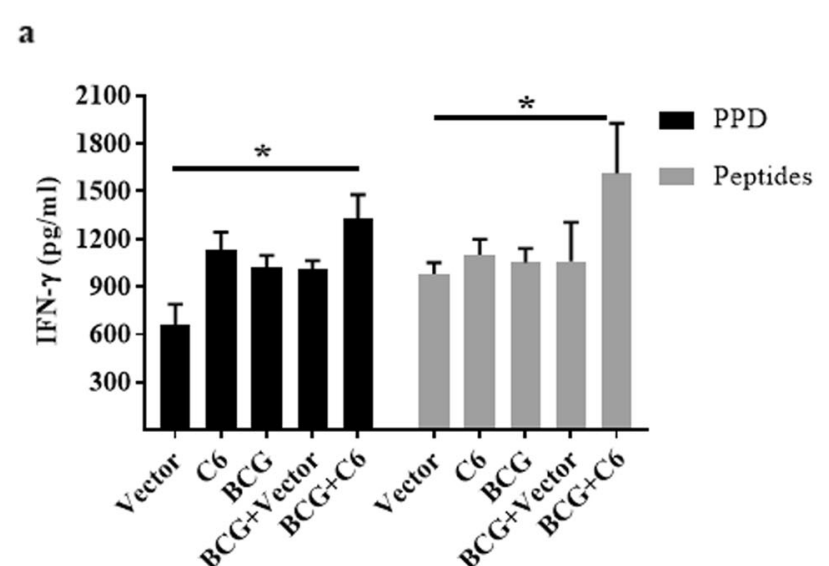

\section{b}
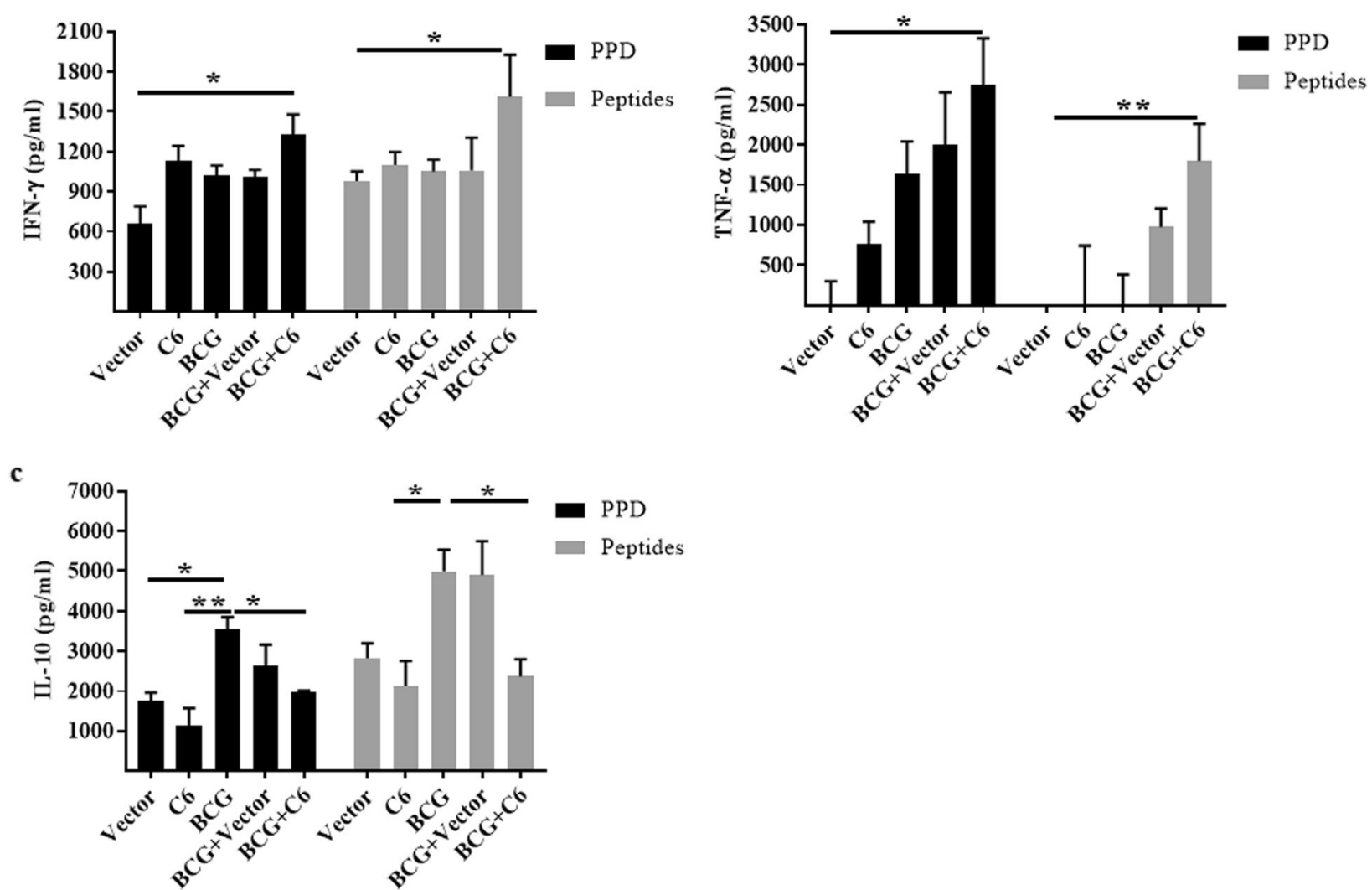

Fig. 4 Immunization with C6 promotes IFN- $\gamma$ and TNF-a secretion and decreases IL-10 release. Thirty days later of the Mtb challenge, lymphocytes of spleen and lymph nodes isolated from the BCG + C6 immunized and control animals were in vitro stimulated for $72 \mathrm{~h}$ with PPD and peptides. Later, culture SNs were harvested and monitored by ELISA for the production of a IFN- $\gamma ; \mathbf{b}$ TNF-a; and $\mathbf{c}$ IL-10. The data shown as mean \pm SEM are from triplicate wells of two independent experiments. ${ }^{*} p<0.05,{ }^{* *} p<0.005,{ }^{* * *} p<0.0005$, ${ }^{* * * *} p<0.0001$ 


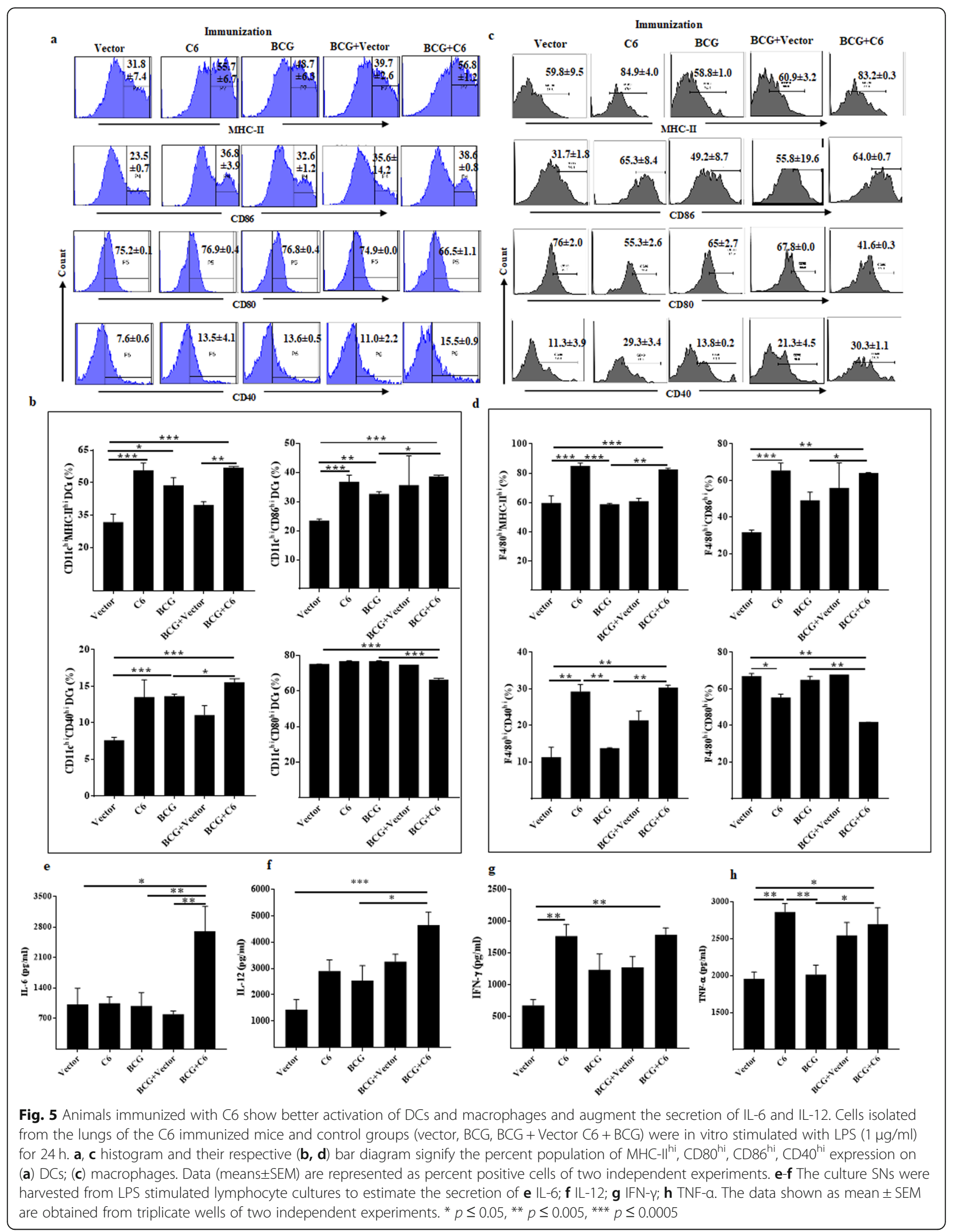


when compared to control groups (vector, BCG), mice inoculated with $\mathrm{BCG}+\mathrm{C} 6$ exhibited significantly higher production of IL-6 $(p<0.05, p<0.01)$ and IL-12 $(p<0.001)$ (Fig. 5e, f). Upon activation, dendritic cells and macrophages produce pro-inflammatory cytokines [23-26]. We monitored IFN- $\gamma$ and TNF- $\alpha$ in LPS stimulated lymphocytes culture supernatant and observed elevated IFN- $\gamma(p<$ $0.005)$ and TNF- $\alpha(p<0.05)$ in the BCG + C6 group compared to vector. Mice treated with BCG did not elicit the same response (Fig. 5g, h). These results signify the important role of $\mathrm{C} 6$ in generating a favourable immune response for clearing $M t b$ infection.

\section{BCG administration with $\mathrm{C} 6$ significantly reduced $M t b$ burden and disease pathology}

We further assessed the protective role of $\mathrm{C6}$ in reducing the pleural mycobacterium burden in $M t b$-infected animals. C6 injected mice were boosted twice with C6. After $45 \mathrm{~d}$, they were aerosol challenged with $M t b . M t b$ burden in the lungs and spleen was assessed $30 \mathrm{~d}$ after infection. Histopathology analysis revealed a reduction in disease pathology in both the lungs and spleen of $\mathrm{C} 6$ and BCG + C6 groups, as compared to negative and vector groups. There was lower peribranchial lymphocyte infiltration in the lungs as well as a decreased number of follicles in the spleen of the C6 and $\mathrm{BCG}+\mathrm{C} 6$ vaccinated mice (Fig. 6a, b). Furthermore, C6 vaccinated animals showed a significant reduction $(p<0.05)$ in $M t b$ CFUs, as compared to control unvaccinated negative and vector inoculated groups (Fig. 6c). Restriction in the dissemination of $M t b$ to the spleen was observed and confirmed by a significant reduction in Mtb CFU (Fig. 6d). It was surprising to note that although $\mathrm{C} 6$ induced a better immune response (Figs. 2, 3, 4 and 5) than BCG vaccinated mice, the decrease in CFUs was similar to BCG vaccinated mice. Furthermore, BCG + C6 animals exhibited a significantly better decline in the bacterial burden $(p<$ $0.05)$, when compared with the BCG vaccinated mice, indicating a synergistic effect between both the vaccines. These results indicate that the efficiency of BCG protection can be considerably bolstered by co-administration of the C6 construct expressing the immunodominant $\mathrm{T}$ cell epitopes of $M t b$.

\section{Discussion}

The poor performance of BCG in TB-endemic areas can be rationalized with multiple explanations. BCG protects the childhood but not adult manifestation of TB [27-30]. Signifying that it lacks the antigenic repertoire that is required in inducing long-lasting protective memory $\mathrm{T}$ cells. Consequently, supplementing $M t b$ antigenic epitopes in BCG may bolster its performance. Therefore, in the

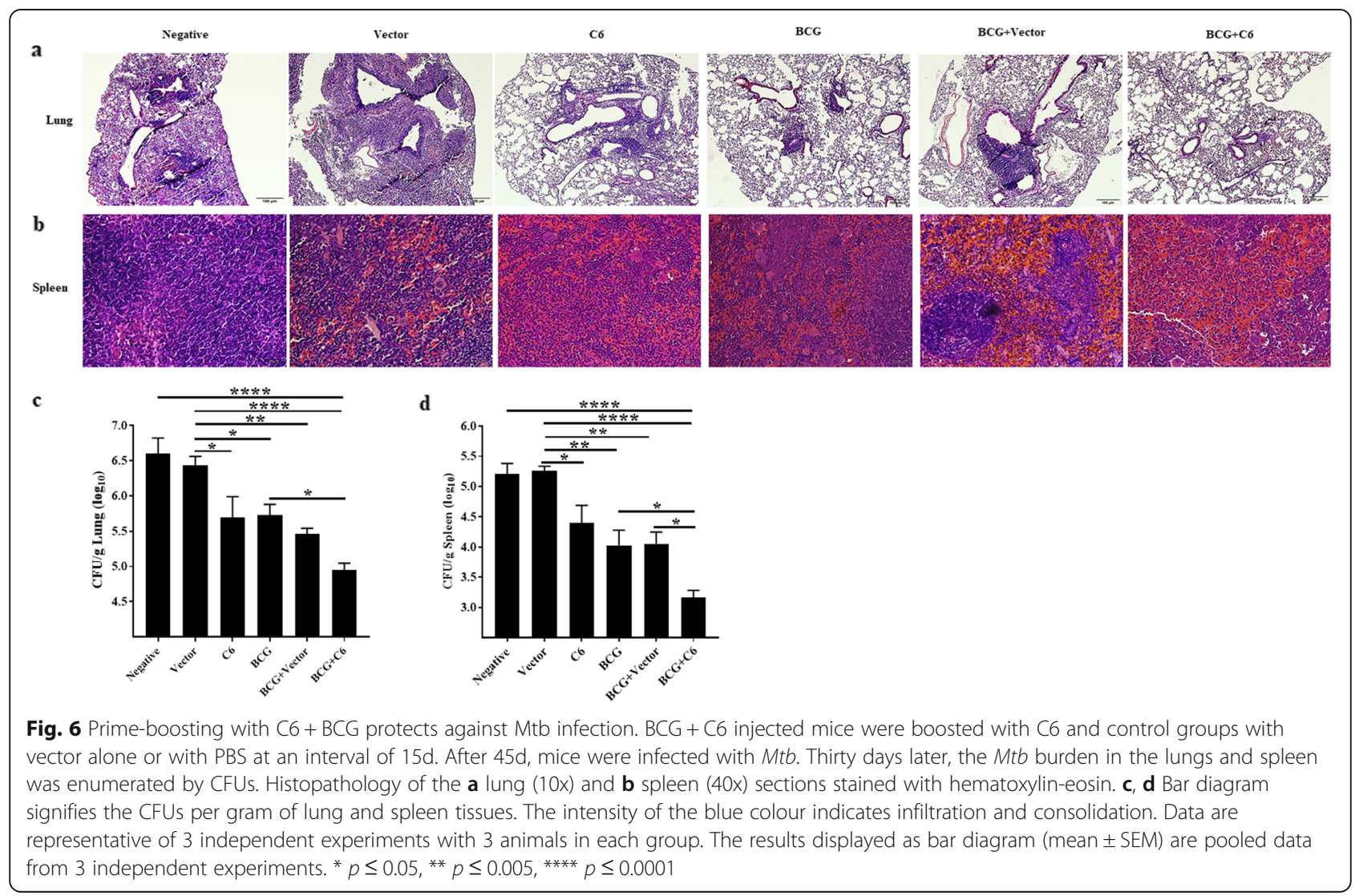


current study, we selected multiple epitopes from latent, active, and chronic stages of TB and synthesized a DNA vaccine to check its efficiency either alone or in a combination of BCG.

It has been previously reported that the Acr1 protein provides enhanced protective efficacy when overexpressed in BCG [31]. However, Acr1 impairs the maturation and functionality of DCs and supports the intracellular survival of $M t b$ [22, 32]. Similarly, Rv2626c protein has been shown to protect against $M t b$, as well as modulate the functionality of macrophages and assist in the escape of pathogen [33, 34]. Hence, the expression of CD4 T cell and CD8 T cell epitopes in a DNA vaccine with BCG may be a better approach to combat TB. Promiscuous $\mathrm{T}$ cell epitopes have enough potential to bind diverse HLA alleles and evoke $\mathrm{T}$ cell activation without requiring extensive antigen processing by APCs $[8,35]$. However, peptide vaccines are weak immunogens and thus require adjuvants to elicit optimum activation of $\mathrm{T}$ cells.

Therefore, we selected and expressed multiple $\mathrm{T}$ cell epitopes from the latent, active, and chronic stages of TB in the DNA vector to overcome the limits associated with BCG. DNA vaccines can induce both CD4 T cells and CD8 $\mathrm{T}$ cell responses against the expressing antigens [10]. This ability has led to the development of many veterinary vaccines and human clinical trials involving Zika, HIV, dengue, and cancer diseases [36-40]. In connection with $\mathrm{TB}$, DNA vaccines have shown the potential to combat infection [41-46]. In this light, we selected six promiscuous CD4 T cell and CD8 T cell epitopes from the different $M t b$ proteins [11-14] and cloned them into pcDNA3.1(-) plasmid. The novelty of the C6 construct is that it has 2 copies of each epitope linked with protease-sensitive amino acid sequences. This allows for APC-mediated protease cleavage and eventual release from C6 expressing cells with the help of a secretory signal (Fig. 1). Furthermore, the use of a plasmid vector helps in the elicitation of the CD8 $\mathrm{T}$ cell response [47]. We generated the YFP reporter construct with C6 by cloning it into the plasmid pcDNA3.1(-) and pEYFP to evaluate its expression and secretion. We confirmed the expression of $\mathrm{C} 6$ along with YFP in vitro into the $\mathrm{CHO}$ cells by fluorescence imaging, as well as Western blotting (Fig. 2). Also, it was important for the construct to be expressed in vivo to evoke an immune response. We immunized animals with $\mathrm{C} 6$ and observed YFP expressing cells in the mice, thus confirming the expression of C6. Furthermore, we examined if the C6 vaccine could enhance the efficacy of BCG. We evaluated the boosting capacity of C6 in BCG vaccinated mice. We noticed following major outcomes on C6 vaccination: (1) generation of memory CD4 T cell and CD8 T cells; (2) enhancement in Th1 responses, as evidenced by the predominant secretion of IFN- $\gamma$ and TNF- $\alpha$; (3) promotion of the activation of APCs; (4) boosting of protective efficacy of BCG against $M t b$.

Immunological memory is an indispensable feature of adaptive immunity that protects organisms from subsequent infections [48]. Moreover, it is a fundamental feature of a successful vaccine [49]. The generation of short-term memory $\mathrm{T}$ cells is one of the reasons for the failure of BCG to impart protection against $M t b$ in the vaccinated adult population [50]. Remarkably, BCG generates better memory $\mathrm{CD} 4 \mathrm{~T}$ cells and $\mathrm{CD} 8 \mathrm{~T}$ cells response with the addition of memory response by $\mathrm{C} 6$ (Fig. 3). The enhancement in memory response could be observed due to the generation epitope-specific immune response. It has been reported that resting $\mathrm{T}$ cell population with naïve phenotype i.e. $\mathrm{CD} 62 \mathrm{~L}^{\text {hi }} / \mathrm{CD} 44^{\mathrm{lo}}$ can confer protection against $M t b$ [51, 52]. The increase in the resting population upon $\mathrm{C} 6$ administration denotes the enhancement in the generation of resting population, which is important for recall response. Intriguingly, C6 potentiated the capacity BCG in augmenting CD62 $\mathrm{L}^{\mathrm{hi}}$ / $\mathrm{CD} 44^{\mathrm{lo}}$. Decreased the percentage of $\mathrm{CD} 44^{\mathrm{hi}} / \mathrm{CD} 62 \mathrm{~L}^{\mathrm{lo}}$ cells in C6 and BCG + C6 indicates the capability of effector cells to transit towards memory cell which is poorly associated with BCG and explain its failure in persistent $M t b$ infections [53-55].

CD4 $\mathrm{T}$ cell subsets express distinct cytokines and transcription factors, thereby responding to different pathogens. Th1 cells protects against $M t b$ by secreting IFN- $\gamma$ and TNF- $\alpha$ and stimulating macrophages to kill intracellular pathogens $[56,57]$. The importance of IFN- $\gamma$ is illustrated as its absence enhances $M t b$ susceptibility, mortality, and defects in macrophage activation [58]. For initiation and maintenance of defence against $M t b$, TNF- $\alpha$ plays a crucial role in reactivation of latent tuberculosis of rheumatoid arthritis patients during the neutralization by the anti-TNF antibody [59]. Therefore, the generation of Th1 immunity by a vaccine is quite crucial to protect against TB. The elicitation of higher yield of IFN- $\gamma$ and TNF- $\alpha$ by BCG + C6 denotes its potential to generate Th1 response (Fig. 4). IL-10 is produced by Th2 cells and can reciprocally regulate the generation of Th1 cells as well as the macrophage and DCs to activate Th1 cells $[60,61]$. Furthermore, it has been shown that BCG infected dendritic cells generate IL-10 producing $T$ cells [62]. we observed elevated expression of IL-10 in the BCG immunized group. In contrast, C6 alone and along with BCG immunization declined the IL-10 secretion, indicating its ability to promote Th1 cells.

The importance of antigen-presenting cells (APCs), such as DCs and macrophages, in the protection against TB is well elucidated [21]. Besides phagocytosing and killing the pathogens, these cells simultaneously process and present the pathogenic components to activate and 
differentiate $\mathrm{T}$ cells into effector and memory $\mathrm{T}$ cells. These activated $\mathrm{T}$ cells help to bolster the function of APCs to release cytokines like IFN- $\gamma$ and TNF- $\alpha[49,56,57]$.

$M t b$ can modulate APCs to restrict the generation of adaptive immunity. Mtb inhibits the maturation of APCs by preventing antigen presentation through $\mathrm{MHC}$ along with costimulatory molecules such as CD86, CD40, and CD80 masks the ability to activate antigen-specific $\mathrm{T}$ cells $[63,64]$. Interestingly, DNA vaccines can activate APCs by interacting with TLR9 [65]. It is noteworthy to mention here that the activation of DCs and macrophages in BCG + C6 immunized animals were higher, as evidenced by the increased percentage of $\mathrm{MHC}-\mathrm{II}^{\mathrm{hi}}$, CD86 ${ }^{\text {hi, }}$ and $\mathrm{CD} 40^{\text {hi }}$ costimulatory molecules expressing cells (Fig. 5). CD80 preferably interacts with CTLA-4 molecule of $\mathrm{T}$ cells and weakly with CD28 and is linked with the generation of anergy and tolerogenic $\mathrm{T}$ cells [66]. The reduction of $\mathrm{CD} 80^{\mathrm{hi}}$ percent population of DCs and macrophage in BCG + C6 supports the generation of pathogenic $\mathrm{T}$ cells rather than tolerance. To activate $\mathrm{T}$ cells and generate effector and memory $\mathrm{T}$ cells, DCs and macrophages produce IL- 6 and IL-12. Thus, activation and secretion of IL- 6 and IL-12 are crucial for the APCs [18]. Increased production of IL- 6 and IL-12 in the BCG + C6 group indicates the enhanced capability of DCs and macrophages to activate T cells. Similarly, the role of IFN- $\gamma$ and TNF- $\alpha$ has been correlated with the functionality of DCs and macrophages [67, 68]. Therefore, the production of IFN- $\gamma$ and TNF- $\alpha$ indicates the activation of DCs and macrophage.

Apart from the generation of optimum activation of the immune system, a cardinal feature of a vaccine is to restrict infection. During the progression of TB, the infiltration of inflammatory mononuclear cells leads to the development of granulomas; a habitable niche for $M t b$ [69]. Furthermore, acute bronchopneumonia and necrotizing granulomas have been correlated with the pathology of pulmonary TB [70]. Remarkably, we observed a decrease in the $M t b$ burden and disease pathology of the lungs of the C6 administered group and augmented the potency of BCG (Fig. 6). C6 prevented the dissemination of $M t b$, as depicted by a decrease in the bacterial burden in the spleen. The reduced bacterial burden in the vaccinated group indicates the protective efficacy of C6 with BCG.

The C6 vaccination along with BCG has improved the protection against the $\mathrm{Mtb}$ in the mice model of $\mathrm{TB}$. Its protective efficacy has been achieved by the generation of memory $\mathrm{T}$ cells against Mtb. These $\mathrm{T}$ cells can activate DCs and macrophages with the help of IFN- and TNF-. Moreover, the DCs and macrophages in immunized animals were not affected by the suppressive ability of $M t b$ and could produce IL- 6 and IL- 12 to further activate T cells. All these together declined the $M t b$ burden in the vaccinated group of animals compared to controls.

\section{Conclusion}

TB has been ranked as one of the world's most deadly diseases. Cumbersome therapeutic strategies, drug-resistant strains, and failures of the common BCG vaccine all further the necessity of efficacious vaccine development. Subunit vaccines have provided a benefit over whole cellbased vaccines $[8,9,71]$. Overall, our studies indicate that a multi $\mathrm{T}$ cell epitope-based DNA vaccine substantially enhances the immunity and protection of BCG against $M t b$. These results affirm the potential viability of $\mathrm{C} 6$ as a vaccine candidate in the effort to control TB.

\section{Methods \\ Mice}

$\mathrm{BALB} / \mathrm{c}$ and $\mathrm{C} 57 \mathrm{BL} / 6$ female mice (6-8 weeks, $16-18 \mathrm{~g}$ ) were obtained from the Animal House Facility, CSIRInstitute of Microbial Technology, Chandigarh (IMTE $\mathrm{CH}$ ) and kept in Biosafety level 3 laboratory in CSIRInstitute of Microbial Technology, Chandigarh (IMTE $\mathrm{CH})$ for experimental procedures.

\section{Bacteria and cell lines}

The Escherichia coli (E. coli) DH5 $\alpha$ strain was grown in LB media and used in this study for cloning and purification of plasmids. BCG Danish strain (Serum Institute of India PVT. LTD., India) used for immunization. $M t b$ $\mathrm{H} 37 \mathrm{Rv}$ strain was grown in $7 \mathrm{H} 9+10 \% \mathrm{OADC}$ and preserved as $10 \%$ glycerol stock at $-80^{\circ} \mathrm{C}$ to be used for infection respectively. $\mathrm{CHO}$ cell line was used for the transfection studies.

\section{Reagents}

All the reagents and primers were purchased from Sigma (St. Louis, MO) and antibodies from eBiosciences (San Diego, CA), Restriction, and ligase enzymes were from New England Biolabs (Ipswich, MA), further unless and otherwise mentioned. Bacterial media were purchased from Himedia (Mumbai, India).

\section{T cell epitopes selection, cloning, and expression}

The promiscuous $\mathrm{T}$ cell epitope selection was based on binding to multiple HLA alleles. We selected 6 promiscuous CD4 T cells and CD8 T cell epitope peptides from the literature. The peptide sequences were arranged in duplicates and linked with a protease-sensitive amino acid sequence (AVYAFVH). An N-terminal human growth hormone (HGH) secretory signal was linked for the secretion of the protein from the host cells. The chimera gene (C6) for the protein was synthesized (GenScript, Piscataway, NJ). To use the C6 gene as a vaccine, a suitable vector must be used for the expression. Consequently, to utilize as a DNA vaccine, vector pcDNA3.1 - was used. The synthesized gene was cloned into the pcDNA3.1- vector at the site of BamHI and 
HindIII and transformed into E. coli DH5 $\alpha$ for multiplication and purification of the plasmid. The presence of the C6 gene in the plasmid was confirmed through colony PCR and agarose gel electrophoresis.

Later, C6 was cloned into the pEYFP-N1 vector at the site of the NheI and HindIII site to generate a YFP tagged protein for the expression confirmation of gene in the host cells. pEYFP-C6 was transformed into E. coli and kanamycin-resistant colonies were screened through colony PCR and agarose gel electrophoresis. To further confirm the expression of $\mathrm{C} 6$ in pcDNA3.1- vector, the C6YFP gene was amplified and cloned into the NheI and NotI site of pcDNA3.1- and transformed into E. coli and positive colonies were selected through PCR and agarose gel electrophoresis. All the plasmids for the use of immunization and transfections were isolated through the Triton X-114 method [72].

The $\mathrm{CHO}$ cell line was transfected with plasmids by using lipofectamine 2000 (Invitrogen, Carlsbad, CA). The standard manufacturer protocol was followed for the transfection. Transfected cells were used for direct observation under a fluorescent microscope, western blotting, and FACS analysis.

\section{Western blotting}

Transfected $\mathrm{CHO}$ cell lysate was prepared by harvesting, washing, and lysis in lysis buffer (RIPA buffer, protease, and phosphatase inhibitor cocktail). The culture supernatants (SN) were precipitated through Acetone precipitation. Briefly, five times a volume of $80 \%$ chilled acetone was added to the $\mathrm{SN}$ and incubated overnight at $-20^{\circ} \mathrm{C}$. Later, SN was pelleted at $10000 \mathrm{~g}$ for $15 \mathrm{~min}$ at $4{ }^{\circ} \mathrm{C}$. The pellets were washed twice with $80 \%$ chilled acetone and air-dried for $45 \mathrm{~min}$ at RT. Pellets were dissolved into PBS. The SNs of the cell lysate and culture SNs were estimated and equal concentration was subjected to SDS-PAGE. After transfer onto nitrocellulose membrane and blocking, the membranes were immunoblotted with Abs against YFP. Blots were developed using a chemiluminescence kit (Thermo Scientific, Waltham, MA). Chemiluminescence was detected by ImageQuant LAS 4000 (GE life sciences, UK).

\section{Animal immunization}

To study the in vivo expression of $\mathrm{C} 6, \mathrm{C} 57 \mathrm{BL} / 6$ mice were vaccinated with $100 \mu \mathrm{g}$ of C6YFP, and inguinal LNs and hind limbs were isolated $3 \mathrm{~d}$ later to check YFP expressing cells. For the immunological studies, BALB/c mice were immunized subcutaneously (s.c.) at the base of the tail with BCG $\left(10^{6} \mathrm{CFU} /\right.$ animal $)$ along with intramuscularly (i.m.) in the hind limb with $100 \mu \mathrm{g} /$ animal of C6 and controls (pcDNA3.1-, C6, BCG and negative) in PBS as 3 mice in a group. Two booster doses of DNA vaccine were given at the interval of 2 weeks. Later, mice were euthanized for organ analysis.

\section{Aerosol infection and bacterial burden in the lungs and spleen}

Immunized mice were rested for $30 \mathrm{~d}$ and aerosol challenged with $100 \mathrm{CFU}$ of live $M t b$ by Inhalation Exposure System (GlasCol, LLC, Terre Haute, IN). Thirty days after the infection, animals were sacrificed and bacterial burden in lungs and spleen were determined by inoculation of tissue homogenates on 7H11 plates. Lungs and spleen sections were also preserved in $1 \%$ formalin in PBS for the histopathological analysis by hematoxylin and eosin staining.

\section{Spleen and lung lymphocyte culture}

Spleen, lymph nodes (LNs), and lung cells were prepared by crushing of tissues followed by RBC lysis. Lymphocytes $\left(2 \times 10^{5} /\right.$ well $)$ isolated from spleens/LNs or lungs were cultured in 96-well $\mathrm{U}$ bottom plates and stimulated with PPD $(25 \mu \mathrm{g} / \mathrm{ml})$ and 5 C6 peptides $(5 \mu \mathrm{g} / \mathrm{ml}$ each) as Rv0476 ${ }_{(1-19)}$ was unable to synthesize. For DCs and macrophages activation status studies, cells were stimulated with LPS $(1 \mu \mathrm{g} / \mathrm{ml})$ for $24 \mathrm{~h}$.

\section{Flowcytometry}

For phenotypic analysis of T cells, the PPD and peptides stimulated lungs and spleen/LNs cells were analysed by flow cytometry. Lymphocytes culture were harvested and stained with fluorochrome tagged anti-CD4-PE, CD8APCCy7, CD62L-FITC, CD44-PerCPCy5.5, CD11cPECy7, F4/80-APC, CD86-PE, CD80-FITC, CD40-PECy5, and MHC-II-PerCPCy5.5abs (BD Biosciences, San Jose, CA). Briefly, lymphocytes were harvested in tubes and washed with FACS buffer (PBS $+2 \% \mathrm{FCS}$ ). Cells were Fc blocked using anti-mouse CD16/CD32 Ab. Later, stained with fluorochrome-labelled Abs. After staining, cells were fixed by using $1 \%$ paraformaldehyde in FACS buffer. Cells were acquired in BD-FACS Aria III and BD-FACS Accuri (BD, Franklin Lakes, NJ). The analysis was performed using BD-FACS DIVA, BD-C6, and Flowjo software (BD, Franklin Lakes, NJ).

\section{Cytokine ELISA}

The expression of different cytokines in the culture supernatants from PPD and peptide stimulated lymphocyte cultures were monitored by sandwich ELISA. Briefly, primary anti-cytokine antibodies were coated on 96-well plates at $4{ }^{\circ} \mathrm{C}$ overnight. Next, wells were blocked with $2 \%$ BSA solution for $2 \mathrm{~h}$ and incubated overnight at $4{ }^{\circ} \mathrm{C}$ with the culture supernatants. Later, plates were incubated $2 \mathrm{~h}$ with biotinylated secondary antibodies and $45 \mathrm{~min}$ with streptavidin-HRP conjugates. OPD- $\mathrm{H}_{2} \mathrm{O}_{2}$ substrates were 
used to determine the concentration of cytokines along with standards by obtaining reading at $595 \mathrm{~nm}$.

\section{Bioinformatic tools}

For the bioinformatic analysis Ligation calculator (http:// www.insilico.uni-duesseldorf.de/Lig_Input.html), PROSPER (https://prosper.erc.monash.edu.au/), SignalP 4.1 Server (http://www.cbs.dtu.dk/services/SignalP/) and PlasMapper (http://wishart.biology.ualberta.ca/PlasMapper/) tools were used.

\section{Statistics}

All the statistical analysis was performed as One-way ANOVA with Tukey's test in Graph Pad Prism (GraphPad Software, La Jolla, CA).

\section{Supplementary information}

Supplementary information accompanies this paper at https://doi.org/10. 1186/s12879-020-05372-1.

Additional file 1: Supplementary Figure 1. C6 gene construction. (a) All the peptide sequences were analyzed by PROSPER software to check their sensitivity to proteases. Different colors indicate different proteases. 'Red colour' designates the sequence of Rv0476, which was found to be most sensitive to protease degradation. (b) The complete gene sequence of C6 (963bp) is shown that was used for the synthesis of the DNA vaccine. Supplementary Figure 2. C6 was cloned successfully into the plasmid. (a) The C6 gene was cloned into pcDNA3.1- and transformed into E. coli. The agarose gel electrophoresis confirms the presence of the C6 gene with the additional size of the restriction site and extra-base pairs used for restriction digestion. C6: positive control, lane 1-8: different E. coli clones. The vector map of pcDNA3.1-C6 with the site was used for cloning. (b) The C6 gene was cloned into a pEYFP-N1 plasmid and transformed into $E$. coli. The agarose gel electrophoresis confirms positive $E$. coli colonies with the C6 gene. Lane 1-10 indicates the different E. coli colonies and $C$ indicates the positive control of the C 6 gene. The vector map of pEYFP-C6 was used for cloning and as an open reading frame. (c) The C6YFP gene was cloned into pcDNA3.1- plasmid and transformed into E. coli. The agarose gel electrophoresis confirms positive E. coli colonies with the C6 gene. Lane 1-6 indicate the different $E$. coli colonies. DEYFP-C6 vector was used as a positive control. The vector map of PCDNA3.1-C6YFP with the site was used for cloning and as an open reading frame. Supplementary Figure 3. C6-YFP expression in $\mathrm{CHO}$ cells. (a) The C6-YFP transfected CHO cells were analyzed by flow cytometry for their fluorescence intensity (YFP) and represented as histogram plots. Data in the inset represent the mean fluorescence intensity (MFI). (b) The bar diagram represents the integrated mean fluorescence intensity (iMFI) of the transfected cells, further, confirm the presence of C6. Data expressed as mean \pm SEM are representative of 2 independent experiments. ${ }^{*} p \leq 0.05$. Supplementary Figure 4. Co-immunization of BCG with $C 6$ augments memory $T$ cell response. Lymphocytes from the lungs were isolated from the BCG + C6 injected and control animals. Lymphocytes were in vitro stimulated with PPD and peptides. $(a, c)$ Contour plots show the percent population of CD62 ${ }^{\text {hi }}$ CD44 $4{ }^{\text {hi }}$ central memory CD4 T cells and CD8 T cells, stimulated with (a) PPD and (c) peptides and represented as (b, d) bar diagrams. Data are from two independent experiments and represented as mean \pm SEM. Supplementary Figure 5. Prime boosting with BCG and C6 enhances the activation of DCS and macrophages. Lymphocytes were isolated from spleen and LNs from the BCG + C6 immunized and control animals. Cells were in vitro stimulated with LPS $(1 \mu \mathrm{g} / \mathrm{ml})$ for $24 \mathrm{~h}$. (a) Gating strategy used for DCs and macrophage cells. $(b, c)$ histogram and their respective $(d, e)$ bar diagram signify the percent population of $\mathrm{CD} 86^{\mathrm{hi}}, \mathrm{CD} 40^{\mathrm{hi}}, \mathrm{MHC}-\mathrm{II}^{\mathrm{hi}}$, and $\mathrm{CD} 80^{\mathrm{hi}}$ expressing (b) DCs and (c) macrophages. Data (means \pm SEM) represented as percent positive cells are of two independent experiments. ${ }^{*} p \leq 0.05,{ }^{* *} p \leq 0.005$, ${ }^{* * *} p \leq 0.0005,{ }^{* * *} p \leq 0.0001$.

Abbreviation

C6: pcDNA3.1 - with multiple T cell epitope of Mtb

\section{Acknowledgments}

We are thankful for Dr. B.N. Dutta for the histopathological analysis of tissues.

\section{Conflict of interest}

The authors declare no conflict of interest.

\section{Authors' contributions}

JNA and SKM designed the study and wrote the manuscript. SKM, MA, DKD, GK, SN, and SS performed the experiments. All the authors read and approved the final manuscript.

\section{Funding}

The study design, data collection, and analysis were carried out under the funding support from the Council of Scientific and Industrial Research (CSIR), India. SKM and GK recipient of fellowships of CSIR, DKD, and SN of DBT, MA of DST, and SS of ICMR, New Delhi.

\section{Availability of data and materials}

All data generated or analysed during this study are included in this article (and its supplementary information files). All the datasets used and analysed are available upon reasonable request from the corresponding author.

\section{Ethics approval and consent to participate}

The uses of animals were permitted by the Institutional Animal Ethics Committees (IAEC) of IMTECH, Chandigarh. The experiments were accomplished conferring to the National Regulatory Guideline issued by Committee for the Purpose of Control and Supervision of Experiments on Animals (No. 55/1999/CPCSEA), Ministry of Environment and Forest, Govt. of India.

\section{Consent for publication}

All the authors give consent for publication of this article.

\section{Competing interests}

The authors declare that there is no conflict of interest.

Received: 28 January 2020 Accepted: 25 August 2020

Published online: 17 September 2020

\section{References}

1. Cardona PJ. What we have learned and what we have missed in tuberculosis pathophysiology for a new vaccine design: searching for the "pink swan". Front Immunol. 2017;8:556.

2. Schaible UE, Linnemann L, Redinger N, Patin EC, Dallenga T. Strategies to improve vaccine efficacy against tuberculosis by targeting innate immunity. Front Immunol. 2017;8:1755.

3. Kaufmann SH. Future vaccination strategies against tuberculosis: thinking outside the box. Immunity. 2010;33(4):567-77.

4. Russell DG, Barry CE 3rd, Flynn JL. Tuberculosis: what we don't know can, and does, hurt us. Science. 2010;328(5980):852-6.

5. Pym AS, Brodin P, Brosch R, Huerre M, Cole ST. Loss of RD1 contributed to the attenuation of the live tuberculosis vaccines Mycobacterium bovis BCG and Mycobacterium microti. Mol Microbiol. 2002;46(3):709-17.

6. Chatterjee S, Dwivedi VP, Singh Y, Siddiqui I, Sharma P, Van Kaer L, Chattopadhyay D, Das G. Early secreted antigen ESAT-6 of Mycobacterium tuberculosis promotes protective T helper 17 cell responses in a toll-like receptor-2-dependent manner. PLoS Pathog. 2011;7(11):e1002378.

7. Kaufmann SH, Weiner J, von Reyn CF. Novel approaches to tuberculosis vaccine development. Int J Infect Dis. 2017;56:263-7.

8. Gowthaman U, Singh V, Zeng W, Jain S, Siddiqui KF, Chodisetti SB, Gurram RK, Parihar P, Gupta P, Gupta UD, et al. Promiscuous peptide of 16 kDa antigen linked to Pam2Cys protects against Mycobacterium tuberculosis by evoking enduring memory T-cell response. J Infect Dis. 2011;204(9):1328-38. 
9. Rai PK, Chodisetti SB, Maurya SK, Nadeem S, Zeng W, Janmeja AK, Jackson DC, Agrewala JN. A lipidated bi-epitope vaccine comprising of $\mathrm{MHC}-\mathrm{I}$ and MHC-II binder peptides elicits protective CD4 T cell and CD8 T cell immunity against Mycobacterium tuberculosis. J Transl Med. 2018;16(1):279.

10. Kutzler MA, Weiner DB. DNA vaccines: ready for prime time? Nat Rev Genet. 2008;9(10):776-88.

11. Agrewala JN, Wilkinson RJ. Differential regulation of Th1 and Th2 cells by p91-110 and p21-40 peptides of the 16-kD alpha-crystallin antigen of Mycobacterium tuberculosis. Clin Exp Immunol. 1998;114(3):392-7.

12. Axelsson-Robertson R, Weichold F, Sizemore D, Wulf M, Skeiky YA, Sadoff J, Maeurer MJ. Extensive major histocompatibility complex class I binding promiscuity for Mycobacterium tuberculosis TB10.4 peptides and immune dominance of human leucocyte antigen (HLA)-B*0702 and HLA-B*0801 alleles in TB10.4 CD8 T-cell responses. Immunology. 2010;129(4):496-505.

13. Kovjazin R, Volovitz I, Daon Y, Vider-Shalit T, Azran R, Tsaban L, Carmon L, Louzoun $Y$. Signal peptides and trans-membrane regions are broadly immunogenic and have high CD8+ T cell epitope densities: implications for vaccine development. Mol Immunol. 2011;48(8):1009-18.

14. Shams H, Klucar P, Weis SE, Lalvani A, Moonan PK, Safi H, Wizel B, Ewer K, Nepom GT, Lewinsohn DM, et al. Characterization of a Mycobacterium tuberculosis peptide that is recognized by human CD4+ and CD8+ T cells in the context of multiple HLA alleles. J Immunol. 2004;173(3):1966-77.

15. Song J, Tan H, Perry AJ, Akutsu T, Webb Gl, Whisstock JC, Pike RN. PROSPER: an integrated feature-based tool for predicting protease substrate cleavage sites. PLoS One. 2012;7(11):e50300.

16. Hall J, Hazlewood GP, Surani MA, Hirst BH, Gilbert HJ. Eukaryotic and prokaryotic signal peptides direct secretion of a bacterial endoglucanase by mammalian cells. J Biol Chem. 1990;265(32):19996-9.

17. Nielsen H. Predicting secretory proteins with SignalP. Methods Mol Biol. 1611;2017:59-73.

18. Lyadova IV, Panteleev AV. Th1 and Th17 cells in tuberculosis: protection, pathology, and biomarkers. Mediat Inflamm. 2015;2015:854507.

19. Lewinsohn DA, Gold MC, Lewinsohn DM. Views of immunology: effector T cells. Immunol Rev. 2011;240(1):25-39.

20. Mihret A. The role of dendritic cells in Mycobacterium tuberculosis infection. Virulence. 2012;3(7):654-9.

21. Guirado E, Schlesinger LS, Kaplan G. Macrophages in tuberculosis: friend or foe. Semin Immunopathol. 2013;35(5):563-83.

22. Amir M, Aqdas M, Nadeem S, Siddiqui KF, Khan N, Sheikh JA, Agrewala JN. Diametric role of the latency-associated protein Acr1 of Mycobacterium tuberculosis in modulating the functionality of pre- and post-maturational stages of dendritic cells. Front Immunol. 2017;8:624.

23. Martinez FO, Gordon S. The M1 and M2 paradigm of macrophage activation: time for reassessment. F1000prime Rep. 2014;6:13.

24. Jin P, Han TH, Ren J, Saunders S, Wang E, Marincola FM, Stroncek DF. Molecular signatures of maturing dendritic cells: implications for testing the quality of dendritic cell therapies. J Transl Med. 2010;8:4.

25. Pan J, Zhang M, Wang J, Wang Q, Xia D, Sun W, Zhang L, Yu H, Liu Y, Cao $X$. Interferon-gamma is an autocrine mediator for dendritic cell maturation. Immunol Lett. 2004;94(1-2):141-51.

26. Vremec D, O'Keeffe M, Hochrein H, Fuchsberger M, Caminschi I, Lahoud M, Shortman K Production of interferons by dendritic cells, plasmacytoid cells, natural killer cells, and interferon-producing killer dendritic cells. Blood. 2007;109(3):1165-73.

27. Young SL, Slobbe L, Wilson R, Buddle BM, de Lisle GW, Buchan GS. Environmental strains of Mycobacterium avium interfere with immune responses associated with Mycobacterium bovis BCG vaccination. Infect Immun. 2007;75(6):2833-40.

28. Sakhno LV, Shevela EY, Tikhonova MA, Nikonov SD, Ostanin AA, Chernykh ER. Impairments of antigen-presenting cells in pulmonary tuberculosis. J Immunol Res. 2015;2015:793292.

29. Lang R, Schick J. Review: impact of Helminth infection on Antimycobacterial immunity-a focus on the macrophage. Front Immunol. 2017;8:1864.

30. Luca S, Mihaescu T. History of BCG vaccine. Maedica. 2013;8(1):53-8.

31. Dey B, Jain R, Khera A, Gupta UD, Katoch VM, Ramanathan VD, Tyagi AK. Latency antigen alpha-crystallin based vaccination imparts a robust protection against TB by modulating the dynamics of pulmonary cytokines. PLoS One. 2011;6(4):e18773.

32. Yuan Y, Crane DD, Simpson RM, Zhu YQ, Hickey MJ, Sherman DR, Barry CE 3rd. The $16-\mathrm{kDa}$ alpha-crystallin (Acr) protein of Mycobacterium tuberculosis is required for growth in macrophages. Proc Natl Acad Sci U S A. 1998; 95(16):9578-83.
33. Bashir N, Kounsar F, Mukhopadhyay S, Hasnain SE. Mycobacterium tuberculosis conserved hypothetical protein rRv2626c modulates macrophage effector functions. Immunology. 2010;130(1):34-45.

34. Danelishvili L, Everman J, Bermudez LE. Mycobacterium tuberculosis PPE68 and Rv2626c genes contribute to the host cell necrosis and bacterial escape from macrophages. Virulence. 2016;7(1):23-32

35. Feng G, Jiang Q, Xia M, Lu Y, Qiu W, Zhao D, Lu L, Peng G, Wang Y. Enhanced immune response and protective effects of nano-chitosan-based DNA vaccine encoding T cell epitopes of Esat- 6 and $F L$ against Mycobacterium tuberculosis infection. PLoS One. 2013;8(4):e61135.

36. Danko JR, Kochel T, Teneza-Mora N, Luke TC, Raviprakash K, Sun P, Simmons M, Moon JE, De La Barrera R, Martinez LJ, et al. Safety and immunogenicity of a tetravalent dengue DNA vaccine administered with a cationic lipid-based adjuvant in a phase 1 clinical trial. Am J Trop Med Hyg. 2018;98(3):849-56.

37. Kumaragurubaran $K$, Kaliaperumal K. DNA vaccine: the miniature miracle. Vet World. 2013;6(4):228-32.

38. Li SS, Kochar NK, Elizaga M, Hay CM, Wilson GJ, Cohen KW, De Rosa SC, Xu R, Ota-Setlik A, Morris D, et al. DNA Priming Increases Frequency of T-Cell Responses to a Vesicular Stomatitis Virus HIV Vaccine with Specific Enhancement of CD8(+) T-Cell Responses by Interleukin-12 Plasmid DNA. Clin Vaccine Immunol. 2017;24(11):e00263-17.

39. Li X, Pushko P, Tretyakova I. Recombinant Hemagglutinin and Virus-Like Particle Vaccines for H7N9 Influenza Virus. J Vaccines Vaccination. 2015;6(3).

40. Morrison C. DNA vaccines against Zika virus speed into clinical trials. Nat Rev Drug Discov. 2016;15(8):521-2.

41. Delogu G, Howard A, Collins FM, Morris SL. DNA vaccination against tuberculosis: expression of a ubiquitin-conjugated tuberculosis protein enhances antimycobacterial immunity. Infect Immun. 2000;68(6):3097-102.

42. Huygen K, Content J, Denis O, Montgomery DL, Yawman AM, Deck RR, DeWitt CM, Orme IM, Baldwin S, D'Souza C, et al. Immunogenicity and protective efficacy of a tuberculosis DNA vaccine. Nat Med. 1996;2(8):893-8.

43. Oksanen KE, Myllymaki H, Ahava MJ, Makinen L, Parikka M, Ramet M. DNA vaccination boosts Bacillus Calmette-Guerin protection against mycobacterial infection in zebrafish. Dev Comp Immunol. 2016;54(1):89-96.

44. Skeiky YA, Alderson MR, Ovendale PJ, Guderian JA, Brandt L, Dillon DC, Campos-Neto A, Lobet Y, Dalemans W, Orme IM, et al. Differential immune responses and protective efficacy induced by components of a tuberculosis polyprotein vaccine, Mtb72F, delivered as naked DNA or recombinant protein. J Immunol. 2004;172(12):7618-28.

45. Wang Q, Lei C, Wan H, Liu Q. Improved cellular immune response elicited by a ubiquitin-fused DNA vaccine against Mycobacterium tuberculosis. DNA Cell Biol. 2012;31(4):489-95.

46. Wozniak TM, Ryan AA, Triccas JA, Britton WJ. Plasmid interleukin-23 (IL-23), but not plasmid IL-27, enhances the protective efficacy of a DNA vaccine against Mycobacterium tuberculosis infection. Infect Immun. 2006;74(1):557-65.

47. Zhou J, Cheung AK, Tan Z, Wang H, Yu W, Du Y, Kang Y, Lu X, Liu L, Yuen KY, et al. PD1-based DNA vaccine amplifies HIV-1 GAG-specific CD8+ T cells in mice. J Clin Invest. 2013;123(6):2629-42.

48. MacLeod MK, Kappler JW, Marrack P. Memory CD4 T cells: generation, reactivation and re-assignment. Immunology. 2010;130(1):10-5.

49. Cooper AM. Cell-mediated immune responses in tuberculosis. Annu Rev Immunol. 2009;27:393-422.

50. Lindenstrom T, Knudsen NP, Agger EM, Andersen P. Control of chronic Mycobacterium tuberculosis infection by CD4 KLRG1- IL-2-secreting central memory cells. J Immunol. 2013;190(12):6311-9.

51. Kipnis A, Irwin S, Izzo AA, Basaraba RJ, Orme IM. Memory T lymphocytes generated by Mycobacterium bovis BCG vaccination reside within a CD4 CD44lo CD62 ligand (hi) population. Infect Immun. 2005;73(11):7759-64.

52. Hengel RL, Thaker V, Pavlick MV, Metcalf JA, Dennis G Jr, Yang J, Lempicki RA, Sereti I, Lane HC. Cutting edge: L-selectin (CD62L) expression distinguishes small resting memory CD4+ T cells that preferentially respond to recall antigen. J Immunol. 2003;170(1):28-32.

53. Cha SB, Kim WS, Kim JS, Kim H, Kwon KW, Han SJ, Eum SY, Cho SN, Shin SJ. Repeated aerosolized-boosting with gamma-irradiated Mycobacterium bovis BCG confers improved pulmonary protection against the Hypervirulent Mycobacterium tuberculosis strain HN878 in mice. PLoS One. 2015;10(10): e0141577.

54. Henao-Tamayo MI, Ordway DJ, Irwin SM, Shang S, Shanley C, Orme IM. Phenotypic definition of effector and memory T-lymphocyte subsets in mice chronically infected with Mycobacterium tuberculosis. Clin Vaccine Immunol. 2010;17(4):618-25. 
55. McKinstry KK, Strutt TM, Swain SL. The effector to memory transition of CD4 T cells. Immunol Res. 2008:40(2):114-27.

56. Sharpe S, White A, Sarfas C, Sibley L, Gleeson F, Mclntyre A, Basaraba R, Clark S, Hall G, Rayner E, et al. Alternative BCG delivery strategies improve protection against Mycobacterium tuberculosis in non-human primates: protection associated with mycobacterial antigen-specific CD4 effector memory T-cell populations. Tuberculosis. 2016;101:174-90.

57. Cooper AM, Dalton DK, Stewart TA, Griffin JP, Russell DG, Orme IM. Disseminated tuberculosis in interferon gamma gene-disrupted mice. J Exp Med. 1993;178(6):2243-7

58. Flynn JL, Chan J, Triebold KJ, Dalton DK, Stewart TA, Bloom BR. An essential role for interferon gamma in resistance to Mycobacterium tuberculosis infection. J Exp Med. 1993;178(6):2249-54.

59. Flynn JL, Goldstein MM, Chan J, Triebold KJ, Pfeffer K, Lowenstein CJ, Schreiber R, Mak TW, Bloom BR. Tumor necrosis factor-alpha is required in the protective immune response against Mycobacterium tuberculosis in mice. Immunity. 1995;2(6):561-72.

60. Fiorentino DF, Bond MW, Mosmann TR. Two types of mouse Thelper cell. IV. Th2 clones secrete a factor that inhibits cytokine production by Th1 clones. J Exp Med. 1989;170(6):2081-95.

61. Moore KW, de Waal MR, Coffman RL, O'Garra A. Interleukin-10 and the interleukin-10 receptor. Annu Rev Immunol. 2001;19:683-765.

62. Madura Larsen J, Benn CS, Fillie Y, van der Kleij D, Aaby P, Yazdanbakhsh M. BCG stimulated dendritic cells induce an interleukin-10 producing T-cell population with no T helper 1 or T helper 2 bias in vitro. Immunology. 2007:121(2):276-82.

63. van Haarst JM, Hoogsteden HC, de Wit HJ, Verhoeven GT, Havenith CE, Drexhage HA. Dendritic cells and their precursors isolated from human bronchoalveolar lavage: immunocytologic and functional properties. Am J Respir Cell Mol Biol. 1994;11(3):344-50.

64. Giacomini E, Iona E, Ferroni L, Miettinen M, Fattorini L, Orefici G, Julkunen I, Coccia EM. Infection of human macrophages and dendritic cells with Mycobacterium tuberculosis induces a differential cytokine gene expression that modulates T cell response. J Immunol. 2001;166(12):7033-41.

65. Kumagai Y, Takeuchi O, Akira S. TLR9 as a key receptor for the recognition of DNA. Adv Drug Deliv Rev. 2008;60(7):795-804.

66. Vandenborre K, Van Gool SW, Kasran A, Ceuppens JL, Boogaerts MA Vandenberghe P. Interaction of CTLA-4 (CD152) with CD80 or CD86 inhibits human T-cell activation. Immunology. 1999;98(3):413-21.

67. Lu L, Bonham CA, Chambers FG, Watkins SC, Hoffman RA, Simmons RL, Thomson AW. Induction of nitric oxide synthase in mouse dendritic cells by IFN-gamma, endotoxin, and interaction with allogeneic T cells: nitric oxide production is associated with dendritic cell apoptosis. J Immunol. 1996; 157(8):3577-86.

68. Redford PS, Murray PJ, O'Garra A. The role of IL-10 in immune regulation during M. tuberculosis infection. Mucosal Immunol. 2011;4(3):261-70.

69. Ehlers $\mathrm{S}$, Schaible UE. The granuloma in tuberculosis: dynamics of a hostpathogen collusion. Front Immunol. 2012;3:411.

70. Gupta M, Lobo FD, Adiga DS, Gupta A. A histomorphological pattern analysis of pulmonary tuberculosis in lung autopsy and surgically resected specimens. Pathol Res Int. 2016;2016:8132741.

71. Rai PK, Chodisetti SB, Zeng W, Nadeem S, Maurya SK, Pahari S, Janmeja AK, Jackson DC, Agrewala JN. A lipidated peptide of Mycobacterium tuberculosis resuscitates the protective efficacy of BCG vaccine by evoking memory $T$ cell immunity. J Transl Med. 2017;15(1):201.

72. Ma R, Zhao J, Du HC, Tian S, Li LW. Removing endotoxin from plasmid samples by triton X-114 isothermal extraction. Anal Biochem. 2012;424(2): $124-6$.

\section{Publisher's Note}

Springer Nature remains neutral with regard to jurisdictional claims in published maps and institutional affiliations.

\section{Ready to submit your research? Choose BMC and benefit from:}

- fast, convenient online submission

- thorough peer review by experienced researchers in your field

- rapid publication on acceptance

- support for research data, including large and complex data types

- gold Open Access which fosters wider collaboration and increased citations

- maximum visibility for your research: over $100 \mathrm{M}$ website views per year

At BMC, research is always in progress.

Learn more biomedcentral.com/submissions 